\title{
VIDA \& MORTE ENTRE POVOS INDÍGENAS
}

JANE FELIPE BELTRÃO ${ }^{1}$

$U F P A$

\section{RHUAN CARLOS DOS SANTOS LOPES ${ }^{2}$}

$U F P A$

MAINÁ JAILSON SAMPAIO CUNHA ${ }^{3}$

$U F P A$

LUIZA DE NAZARÉ MASTOP-LIMA ${ }^{4}$

UFPA/UNIFESPA

WILLIAM CÉSAR LOPES DOMINGUES ${ }^{5}$

$U F P A$

TIAGO PEDRO FERREIRA TOMÉ ${ }^{6}$

$U F P A$

RESUMO: Considerando as frequentes violações de direitos perpetradas contra os povos indígenas, atingindo territórios e pessoas, comprometendo a vida e até o direito de prantear os mortos, torna-se imperioso conhecer os cuidados e as apreensões dos indígenas em relação à vida e à morte. Para isso, propomos analisar narrativas etnográficas acerca dos Apinayé, Ka'apor, Tapirapé, Tembé, Tenetehara, Terena e Asurini, a fim de discutir o cuidado com as pessoas, tendo em vista os contextos dos rituais funerários. Os textos analisados são capazes de revelar (1) a existência (ou não) da prática; (2) os contextos específicos em que os rituais

\footnotetext{
${ }^{1}$ Antropóloga e historiadora, docente junto aos programas de Pós-Graduação em Direito (PPGD) e em Antropologia (PPGA), ambos na Universidade Federal do Pará (UFPA). Pesquisadora 1C do CNPq. Email: janebeltrao@gmail.com.

2 Arqueólogo, doutorando no Programa de Pós-Graduação em Antropologia (PPGA) da Universidade Federal do Pará (UFPA). Bolsista CAPES. E-mail: rhuan.c.lopes@gmail.com.

${ }^{3}$ Advogado, formado pela Universidade Federal do Pará. E-mail: mainapn@ gmail.com.

${ }^{4}$ Antropóloga, doutoranda no Programa de Pós-Graduação em Antropologia (PPGA) na UFPA. Docente junto à Universidade Federal do Sudeste do Pará (UNIFESPA). E-mail: luizamastop@ gmail.com.

${ }^{5}$ Indígena da etnia Xakriabá, vive entre os Asuriní do Xingu desde o final da década de 1990. Mestrando no Programa de Pós-Graduação em Antropologia (PPGA) da Universidade Federal do Pará (UFPA). Docente do Curso de Licenciatura e Bacharelado em Etnodesenvolvimento do Campus de Altamira da UFPA. É presidente do Conselho Distrital de Saúde Indígena (CONDISI) de Altamira e Coordenador Adjunto do Fórum de Presidentes de CONDISI. E-mail: uwiraete@gmail.com.

${ }^{6}$ Arqueólogo, docente do programa de Pós-Graduação em Antropologia (PPGA). Pesquisador do Centro de Investigação em Antropologia e Saúde, Universidade de Coimbra, e do Grupo Quaternário e Pré-História do Centro de Geociências (uID 73 - FCT). E-mail: tiagotome@ @mail.com.
} 
funerários são (ou não) praticados; e (3) os sentidos que a prática assume em sociedades etnicamente diferenciadas. As narrativas sobre os povos indígenas vêm à discussão na tentativa de "fazer ouvir" os povos que, hoje, se veem acusados tanto pela mídia e como por organizações (ditas) pró-vida. Portanto, usando da literatura clássica estuda-se o patrimônio de práticas rituais que, para além de conferirem dignidade aos mortos, indicam de forma peremptória que a vida é o bem maior entre os povos indígenas.

PALAVRAS-CHAVE: povos indígenas; vida; morte; ritual funerário; sepultamento.

ABSTRACT: Considering the frequent rights violations perpetrated against indigenous peoples, which affect people and territories, compromising their lives and even their right to mourn the dead, it is imperative to understand the care and concerns of the indigenous towards life and death. Thus, we propose to analyze ethnographic narratives about the Apinayé, Ka'apor, Tapirapé, Tembé, Tenetehara, Terena and Asurini, in order to discuss the caring of people, considering the context of funerary rituals. The texts analyzed are able to reveal: (1) the existence (or not) of the practice; (2) the specific contexts in which the funeral rites are (or not) practiced; and (3) the meanings that the practice gain in ethnically differentiated societies. The narratives of indigenous peoples are included in order to attempt to make the peoples that nowadays find themselves accused by both the media and (reportedly) pro-life organizations "be heard". Therefore, using the classical literature we study the heritage of ritual practices, which besides confering dignity to the dead, indicate that life is the greater good among indigenous peoples.

KEYWORDS: indigenous peoples; life; death; funerary ritual; burial.

\section{Por que falar de vivos e mortos}

A morte de um membro de uma comunidade corresponde a um fenômeno de disrupção do quotidiano desse grupo, que gera sentimentos de perda e pesar nos indivíduos mais ou menos próximos ao falecido. Ainda que a noção da finitude da vida derive da autoconsciência inerente ao ser humano, sendo, por isso, um fenômeno universal à humanidade (PALGI e ABRAMOVITCH, 1984), tal não torna mais evidente que se consiga facilmente racionalizar a morte de um ente querido. A partir do momento em que ocorre a morte, o falecido adquire um novo estatuto e entra em um novo estado, marcado pela progressiva decomposição do cadáver.

É como uma forma de lidar com a disrupção ocorrida, com os sentimentos gerados pela perda de alguém próximo e com esse processo de corrupção e decomposição do corpo que podemos entender as diversas práticas funerárias aplicadas por grupos humanos por todo o mundo. E é também por isso que, por mais variadas que sejam essas 
práticas de tratamento dos mortos, a sua existência é também um fenômeno universal à humanidade.

Em Antropologia, considerando os campos disciplinares, é necessário estar atento ao diálogo entre vivos, oriundos da Antropologia Social, presentes nos estudos de Etnologia Indígena ou Quilombola, correspondendo aos autóctones e aos africanos transplantados; e mortos, que permanecem nos sítios arqueológicos, cuidadosamente "acomodados" em urnas funerárias ou em vestígios de ossos que produzem desafios aos bioantropólogos, pelo xadrez de compreensão que produzem. Por outro lado, os estudos de Linguística Antropológica aproximam antropólogos sociais, bioantropólogos e arqueólogos, considerando os vocabulários que desde muito cedo viajantes e naturalistas recolheram e que oferecem indicações a partir dos topônimos e dos etnônimos7. O entrelaçamento das compreensões produzidas pelos campos disciplinares da Antropologia permite formular pressupostos sobre mudanças e permanências entre os grupos étnicos hoje, na contemporaneidade, e ontem, no passado recente e remoto.

Tendo isto em vista, este artigo propõe refletir as associações e a possibilidade de formular interpretações e teorias mais satisfatórias em Antropologia. Partimos do cotejo, ainda que preliminarmente, dos registros etnográficos referentes aos diários de campo de três antropólogos brasileiros: Darcy Ribeiro (1996), Eduardo Galvão (1996) e Roberto Cardoso de Oliveira (2002), que demonstram preocupação com formas e procedimentos em relação à morte entre os povos indígenas, mesmo não sendo o tema foco de seus trabalhos ${ }^{8}$. Na sequência, dois trabalhos monográficos, hoje clássicos, são tomadas a termo: o primeiro de Curt Nimuendajú (1956), e o segundo de Herberth Baldus (1970), na perspectiva de trabalhar as maneiras jê e tupi de morrer e cuidar dos mortos. Por fim, encerramos as reflexões com observações etnográficas efetuadas pelos autores deste artigo, feitas entre três grupos étnicos: os Aikewára, localizados no sudeste do Pará, conhecidos na literatura etnográfica como Suruí do Pará; os Tembé/Tenetehara, ditos de Santa Maria do Pará, ao nordeste do mesmo estado; e os Asurini, também do

\footnotetext{
${ }^{7}$ Sobre o assunto, consultar Menéndez (2002).

${ }^{8}$ Informa-se que as discussões sobre a publicação de diários de campo, na Antropologia, não são ignoradas, mas deixa-se a mesma à margem do texto, pois trabalha-se com os dados etnográficos oferecidos pelos autores que, para fins do artigo, são essenciais.
} 
sudeste paraense.

Para além dos propósitos declarados, informamos que o interesse em estudar a morte e os mortos visa indicar a humanidade dos povos indígenas, considerando que, classicamente, o antropólogo exercita o papel de tradutor cultural no embate com as visões estereotipadas sobre povos tradicionais.

\section{A morte e seus contornos}

Nenhum dos antropólogos citados neste artigo, nem mesmo nós, presenciamos a morte em si mesma, tenham elas ocorrido entre os Apinayé (NIMUENDAJÚ, 1956); os Tapirapé (BALDUS, 1970); os Kaapor (RIBEIRO, 1996); os Tenetehara, os Kaioá e os Xinguanos (GALVÃO, 1996); os Terena e os Tikuna (CARDOSO DE OLIVEIRA, 2002); ou, ainda, entre os Aikewára (BELTRÃO, MASTOP-LIMA e MOREIRA, 2008), Tembé/Tenetehara ou Asurini. No entanto, buscamos o diálogo entre estes relevantes registros etnográficos produzidos por esses trabalhos etnográficos, hoje clássicos, e a escrita que se faz a partir do relato de nossos interlocutores, alguns dos quais extremamente minuciosos e importantes para o diálogo entre os campos da Antropologia. Dos autores do presente texto, Beltrão e Mastop-Lima, apesar de não terem presenciado a morte, estiveram presentes e acompanharam o ritual funerário entre os Aikewára "por acaso", pois chegaram à aldeia no dia do evento. Domingues também não assistiu à morte do parente ${ }^{9}$, mas, como liderança que é, participou das decisões e do ritual entre os Asurini.

Dos textos etnográficos que coligimos, procuramos localizar informações que indiquem os procedimentos em relação à morte, mesmo considerando que os relatos descritos nos diários de campo correspondem a informações "fortuitas", visto que nenhum dos seus autores, até onde temos conhecimento, dedicam-se ao estudo do fenômeno da morte (RIBEIRO, 1996; GALVÃO, 1996; CARDOSO DE OLIVEIRA, 2002); por outro lado, os relatos monográficos são mais detalhados (NIMUENDAJU, 1956; BALDUS, 1970). Os dados apresentados

\footnotetext{
${ }^{9}$ Entre os povos indígenas, "parente" é a denominação oferecida a qualquer outra pessoa indígena, como forma de afirmar a identidade comum, mesmo pertencendo a outro grupo étnico.
} 
nesses textos procuram indicar, em quaisquer das situações, como os povos indígenas vivenciam a morte e quais são os procedimentos usuais, ou mesmo diferenciados, em face da morte em si - acidental, perpetrada por crime ou vingança e natural. As condições da morte: natimortos, recém-nascidos, crianças, jovens, adultos e velhos. Consideram, ainda, quem é o morto, que posição social ocupa, a que sexo pertence o morto e faixa etária do desaparecido. Cuidadosamente, informam os procedimentos rituais - compreendendo preparo do corpo, encomendação e obrigações com o morto, além de indicarem as formas de enterramento que classificam de primário, secundário, em diversos lugares, variando entre a casa, a aldeia, a mata ou o cemitério.

\section{Os Ka'apor ${ }^{10}$}

Darcy Ribeiro (1996) relata que, em julho de 1929, após a mudança do posto indígena, os Ka'apor ocuparam o antigo barracão que servia à unidade do Serviço de Proteção aos Índios (SPI) e por lá costumavam esperar os indígenas que viajavam para outras localidades. O barracão fazia a conexão entre as aldeias e servia de posto de espera. Após uma dessas viagens, os indígenas foram acometidos por gripe e alguns não conseguiram chegar ao destino.

[C]ontinuando a viagem cada vez mais doentes. Quando alcançaram o Itacoary, um ou dois deles não resistiram mais e tiveram que ficar. Morreram dois dias depois. Outros chegaram alquebrados ao posto. Aí eram esperados pelos parentes, a gente do capitão Arara, cujo filho vinha muito mal. Os índios caíram em desespero ao saberem da morte dos companheiros e, vendo o estado dos que alcançaram o posto, choraram de fazer dó, lamentando-se e maldizendo a viagem (RIBEIRO, 1996, p. 29).

O capataz do Posto, por nome Araújo,

[...] vendo que o filho de Arara estava muito mal e com a intenção de curá-lo, deu lhe um purgante de jalapa. No

\footnotetext{
${ }^{10}$ Uso a autodenominação do grupo evitando a denominação Urubu-Kaapor utilizada na Etnologia antes do advento das reivindicações dos movimentos indígenas, quando escreveu Ribeiro (1996).
} 
dia seguinte o rapaz morreu. Foi um desespero maior ainda. Arara que vinha consolando os outros, desesperou-se com a morte do rapaz, supondo que o remédio Ihe fora fatal. Chorava e gritava, atirando flechas no ar para ferir Tupã [...] Enterraram o filho de Arara na ilha onde antes estava o posto. Logo após o enterro, Arara afastou-se para a sua aldeia com toda a sua gente. Voltou ao posto dois meses depois. Estava anos mais velho, era enorme o seu abatimento pela perda do filho. Já muito doente, dizia que viera para morrer junto do filho. De fato, morria ali quinze dias depois (RIBEIRO, 1996, pp. 29-30).

Ribeiro registra que:

[...] seu cadáver [de Arara] foi posto na casa com os pés voltados para fora Amoitaré [tuxaua, chamado para assistir Arara] de pé junto do morto, com a mão espalmada sobre a sua testa iniciou a recomendação [...] naquela hora acabava um cabo de guerra, o seu braço direito. O tuxaua falava chorando [...] O tuxaua e alguns índios mais, junto com os funcionários acompanharam o corpo até a ilha, enterrando-o ao lado da sepultura do filho (RIBEIRO, 1996, p. 30).

As mortes acarretaram dificuldade e Araújo acabou flechado pelos índios, em face de produzir, com seu remédio, a morte do filho de Arara, os funcionários fugiram aterrorizados, só mais tarde voltaram ao posto para enterrar os mortos.

É importante pensar que a morte foi produzida ,"encomendada", que foi a partir da "doenças de branco" que o cerco da pacificação provocou.

Ribeiro produz outra observação importante em seu diário, diz ele;

[s]oube algumas coisas sobre morte e enterramento. Quando um parente adoece, qualquer que seja o parentesco, the dão assistência, ajudam a obter alimentos e o consolam, às vezes até dão um remédio. Se a doença é desconhecida e perigosa, o parente fica ameaçado de ser abandonado sozinho, o que tem acontecido muitas vezes em caso de catarro, sarampo e outras doenças contagiosas. Somente as relações de paia-filho, marido e mulher e entre irmãos parecem ser bastante fortes para resistirem a essa provação (RIBEIRO, 1996, p. 120). 
Comenta Ribeiro que,

[q]uando a doença começa a atacar uma aldeia, todos a abandonam, ao menos todos os que estão sadios e logo depois, os próprios doentes e seus parentes mais próximos que os estão cuidando ganham também a mata. A idéia de que o mal que os assolou está na aldeia, em suas casas e roças. Vêem a doença como uma entidade mística que tem de ser evitada e até enganada, que os perseguem pessoalmente e da qual se podem esconder (RIBEIRO, 1996, p. 120-121, sic).

As doenças produzem o abandono de doentes e mortos. Se alguém morre de dia o corpo é levado para o mato dentro da própria rede do morto. Lá deixam ficar coberto por um tapirizinho com fogo embaixo e voltam à aldeia "na carreira". Depois se tomam as devidas providências.

Em outras ocasiões, quando não há sepultamento, a rede do morto é dobrada sobre o mesmo e ela é "fechada" e "enlinhada" com corda, como um rolo de fumo. E deixada na mata. Se for necessário sepultar, cavam uma cova funda e comprida que possa abrigar a rede e o morto. Para tanto:

[f]incam dois paus no fundo e neles atam a rede com o defunto. Por cima sem tocar no cadáver, fazem uma armação de paus que cobrem com folhas e depois, a enterram até o nível do chão. Então arrumam um pequeno tapiri em cima e dentro dele deixam farinha, água tabaco e um foguinho aceso. Além do fogo e alimentos, o morto recebe suas armas, mas o homem vai nu e a mulher apenas com a tanguinha usual, ambos sem qualquer adorno (RIBEIRO, 1996, p. 121). 
VIDA \& MORTE ENTRE POVOS INDÍGENAS

Figura 1 - Abertura de sepultura por Urubu-Kaapor.

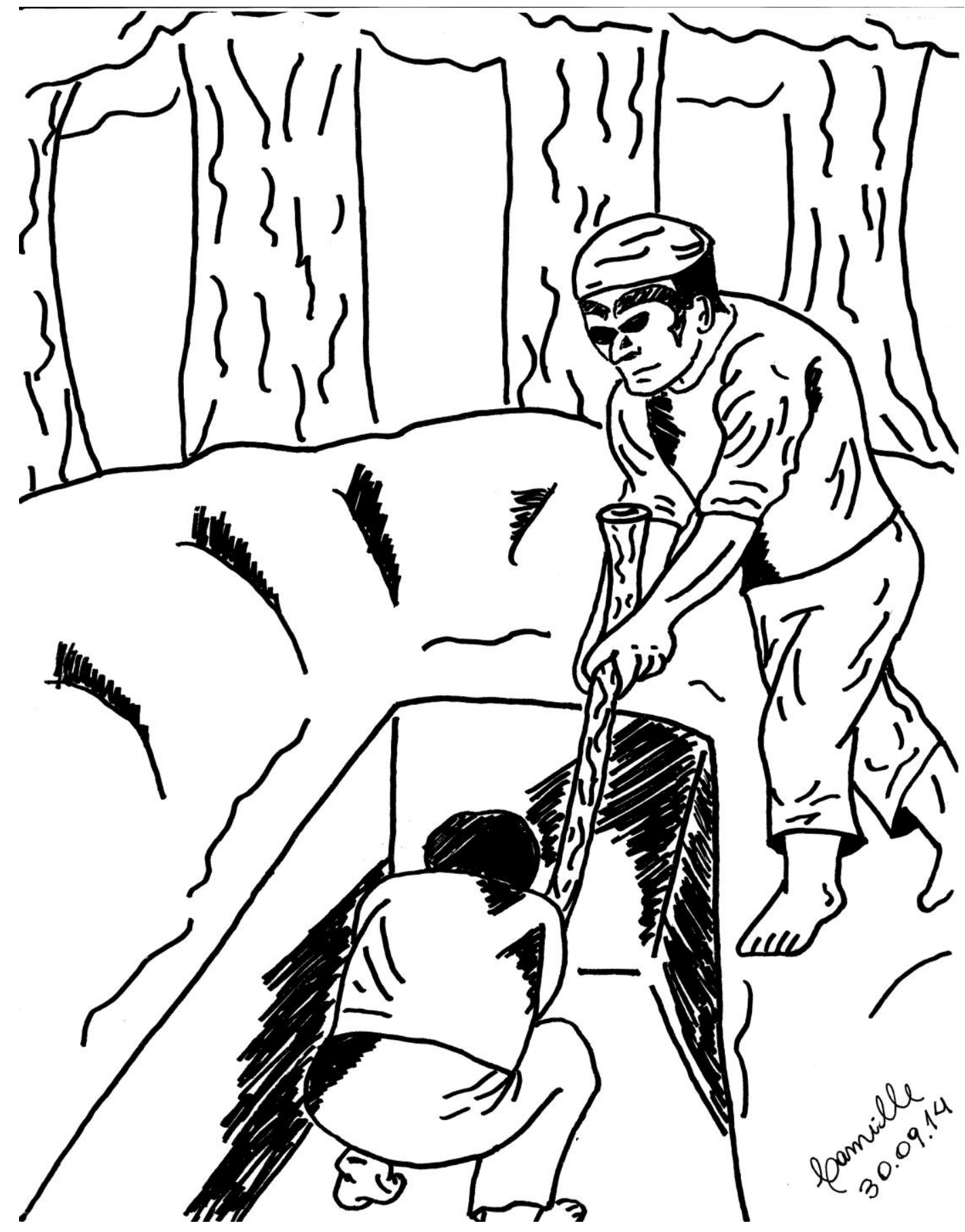

Fonte: Adaptado de Ribeiro (1996, p. 121). Reprodução: Camille Castelo Branco. 
Figura 2 - Desenho esquemático de sepultura.

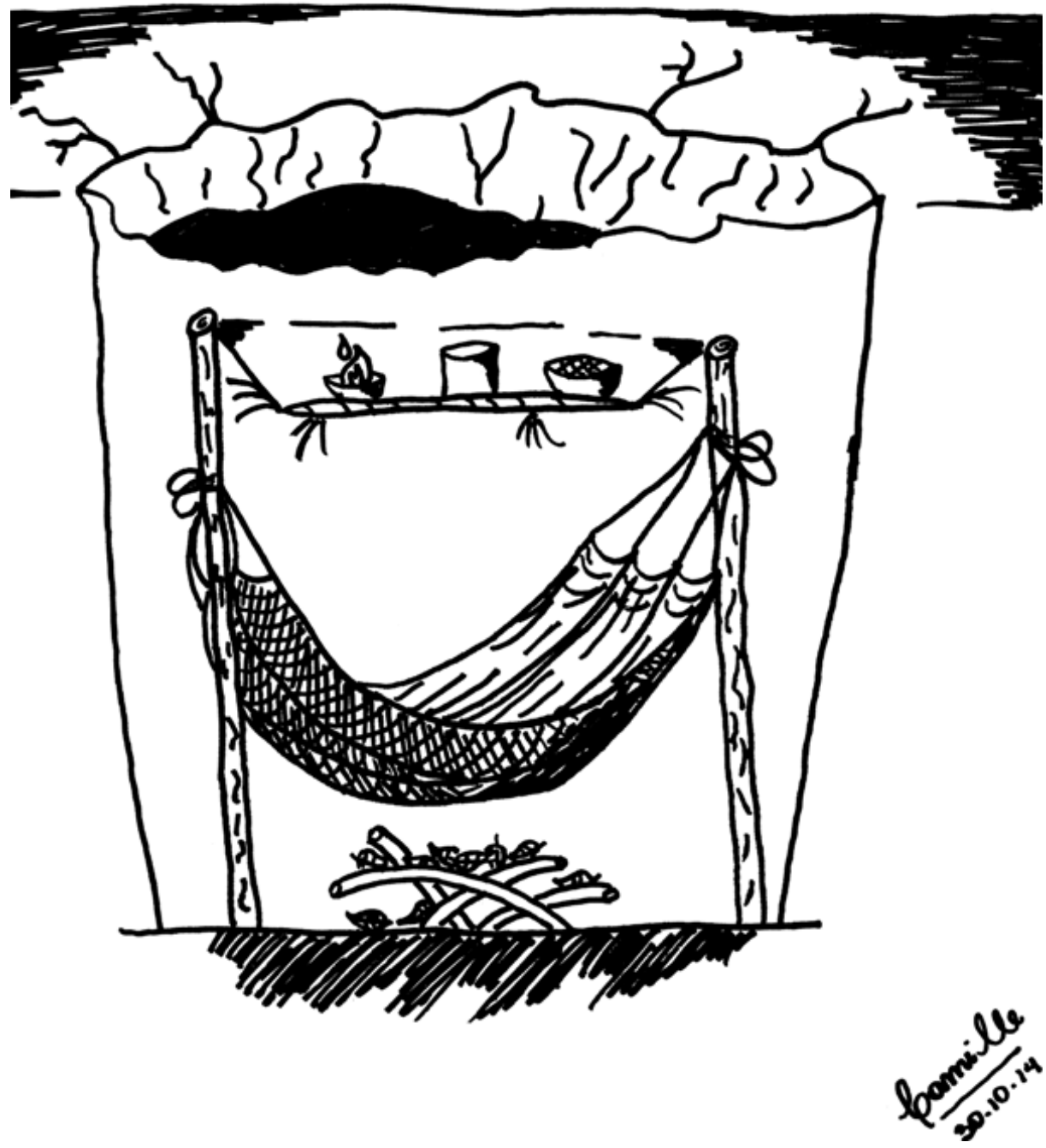

Fonte: Adaptado de Ribeiro (1996, p. 121). Reprodução: Camille Castelo Branco.

Tomam cuidados para não serem "procurados" pelos mortos, por essa razão:

[a]lém de atar o cadáver na rede ... tomam outros cuidados para que o morto não os persiga. Abandonam a aldeia para fugir a zoeira que o parente vai fazer para amedrontá-los e despistam o caminho de volta da sepultura, atravessando-o com paus, abrindo novas picadas ou fazendo clareiras na mata. A morte é um inimigo perigoso e traidor (RIBEIRO, 1996, p. 121).

Quando as pessoas "sentem" a morte chegar, “... chama os parentes e distribui seus bens, as roupas, os adornos todos os seus 
pertences" (RIBEIRO, 1996, p. 121). Caso não faça, os parentes se apropriam dos bens, presenteiam-se.

As crianças podem ser enterradas na casa de seus pais, debaixo da rede da família, mas os adultos não, mesmo sendo tuxauas.

\section{Os Tenetehara}

Os diários de campo de Galvão (1996) contemplam viagens com entrada no território do povo Tenetehara, Kaioa e povos do Xingu; entretanto, as informações predominantes são referentes ao primeiro grupo.

Em relação às crianças tenetehara, diferentes meios de enterramento são praticados, a depender da maneira como a criança foi concebida e da situação das relações conjugais dos pais. No casamento celebrado entre os Tenetehara, o homem, ao casar com mulher que tem filhos, deve cuidar das crianças como sendo suas. Por outro lado, se o rapaz casa com mulher anteriormente grávida, a criança, ao nascer, é enterrada debaixo da rede. O mesmo destino pode ser aplicado aos filhos da mulher sem marido: caso a mãe queira criar o filho, não há obstáculos sociais que a impeçam, mas, se não quer, principalmente por não ter a figura masculina responsável pela obtenção de alimentos, enterra a criança debaixo da rede, embrulhada em panos velhos.

Caso peculiar é o estabelecimento do vínculo paterno. Aquele que primeiro mantém relações sexuais com a mulher é considerado pai da criança, mas no caso de morte do primeiro marido, o atual passa a ser considerado o pai. Ao nascer, a criança chama o segundo de pai, ou aquele que estiver casado com sua mãe.

Quando a criança morre logo após o parto, ou quando nasce morta, é enterrada dentro de casa. Se morrerem mãe e filho durante o parto, a mãe é enterrada no cemitério, mas a criança o é dentro de casa. Quando apenas a mulher morre no parto, a criança, tendo algum parente para cuidá-la, é criada. Fora disso, Galvão relata que era enterrada junto com a mãe.

Quando morre um homem tenetehara, a herança é deixada para o filho do sexo masculino, porém, quando este é pequeno, a propriedade 
passa temporariamente para a mãe, até que o herdeiro cresça. Havendo muitos filhos, o mais velho é o herdeiro. Se o filho mais velho for mulher e existir um filho pequeno, a primeira toma conta das coisas até que o irmão cresça. Quando crescidos, a propriedade é dividida entre ambos. Note-se que mesmo em relação à propriedade entre vivos, quando a mulher briga com o marido, é ela quem sai de casa levando algodão, redes, cabaças, contas e filhos.

Em relação aos povos do Xingu, destaca-se o seguinte trecho do livro, sobre morte supostamente causada por feitiçaria:

[f]oi trazida uma Suiá, jovem, já nas últimas: disenteria e dor de barriga. Chegou com a respiração acelerada, extremidades frias. Foi medicada, mas apagou após uma hora. Diz Cláudio que, já há tempos passados, foi tivera um colapso, tratada por médico, que diagnosticou qualquer insuficiência cardíaca. Veio com o pai e irmãos. Ainda agonizava, quando começaram as lamentações. Todos acocorados em volta da rede, a irmã segurando a cabeça. Choro dirigido pelo pai, em falsete. Meia-noite, levaram-na de volta para a aldeia (cerca de 2 horas e meia daqui), para o enterro. Enterro simples, fora de casa. Alguns já foram enterrados no Posto. Afora os parentes imediatos (duas Suiá casadas com Jawaritu), atitude de indiferença e alguma curiosidade. As mulheres Trumai não apareceram, e dos homens, apenas uns dois. Lituari ficou ausente. Tem uma velha história de suspeita de feitiço. Os Kaiabi foram espiar bastante, ainda vieram perguntar se a menina tinha morrido. Pergunta que pode parecer cretina, pois acompanharam o desenlace, mas pode, também, refletir uma atitude sobre o processo de morrer. Feitiço. Começou logo a falação sobre feitiço, teria sido provocado pelos Kalapalo, o grupo que aqui esteve, no princípio do mês. As suspeitas começaram a se acumular, pelas coincidências. Duas mulheres de Jawaritu abortaram, de modo complicado. Um bando de crianças tem passado mal, com malária e gripe, dois ou três casos degenerando em broncopneumonia. As suspeitas são partilhadas pelos Kaiabi e Juruna. Arakatú já nos comunicou que vai levar Lituari, para tirar feitiço da sua aldeia. E como preventivo, já fez uma cura no braço, com Lituari (GALVÃO, 1996, p. 357, sic.).

\section{Os Terena}


Antes de iniciar a descrição sobre os ritos funerários apresentados por Cardoso de Oliveira (2002), destaca-se um dos mitos terena que, dentre outros temas, trata sobre a morte.

De acordo com o que foi contado a Cardoso de Oliveira (2002), havia um maço de exerogupi (capim) no meio de um lugar chamado Etxíuá, no pantanal (na margem ocidental do Rio Paraguai). A gente moça terena teria tirado, pelo buraco do exerogupi, outros Terena de debaixo da terra, estes, ao serem tirados, saíam tremendo de frio e se encolhiam no chão. Uma velha saiu pelo buraco, mas esqueceu de trazer seu hupaié (fuso), ela quis voltar para buscá-lo e assim fez, contudo não pode retornar para cima porque foi tapada por Pitanoé, um dos irmãos gêmeos terena. Assim, metade do povo Terena ficou tapada embaixo da terra, sem poder sair. Pelo que se sabe, ainda pode existir gente terena lá embaixo. Acredita-se que é em razão do enterramento da velha que voltou para pegar seu hupaié que os Terena passaram a morrer.

Após a breve narrativa mitológica, que relaciona morte e enterramento, destaca-se desde logo que Cardoso de Oliveira (2002) entra no território terena após acontecimentos que modificaram significativamente a vida do povo, como a difusão das religiões cristãs e, sobretudo, as epidemias trazidas pelo contato com a sociedade envolvente, as quais dizimaram severamente a população.

O capitão Francisco Vitorino destaca o luto da comunidade diante do número elevado de mortes provocadas pelas epidemias advindas do contato com os não indígenas. De acordo com o capitão, antigamente os homens não permitiam que os cabelos crescessem enquanto não terminasse o luto. O período estimado era proporcional ao grau de parentesco existente entre o morto e o enlutado: para morte dos pais, luto de um ano, e para falecimento de outros parentes, luto de seis meses.

As mulheres, por outro lado, cortavam os cabelos três dedos acima das pontas e os deixavam crescer até o término do luto. $O$ uso da roupa preta para as Terena era considerado item essencial, os vestidos eram tingidos utilizando casca de aroeira e sementes de genipapo. O luto despendido pelas mulheres abrangia, ainda, retiro residencial de quatorze dias quando do falecimento de pais, e de cinco dias pela morte de filhos e demais parentes. A notícia da morte de crianças é dada aos 
demais por uma mulher correndo, aos gritos, pela aldeia, anunciando o falecimento. Durante o trajeto do corpo ao cemitério, algumas vezes uma das carpideiras sai correndo na frente do cortejo e volta entoando cânticos de lamentação, pontilhados por gritos lancinantes.

Quando Cardoso de Oliveira (2002) estava entre os Terena, década de 1960, a manifestação do luto ocorria somente com o uso de roupas pretas e costumava-se comprar o tecido tingido.

Outro interlocutor de Cardoso de Oliveira (2002), o capitão Timóteo, relata que o velório de sua mãe, falecida com 110 anos de idade, começou às oito horas da noite, com cantos e rezas; repetindo-os ao aproximar da meia-noite; e novamente às duas da madrugada. Por três vezes os homens e as mulheres cantaram e rezaram. Ao amanhecer, o corpo foi levado para a igreja, outra vez as mulheres cantaram e rezaram. Durante a última parte foi o cortejo ao cemitério, em lugar de rezarem, apenas choraram e lembraram as virtudes e a longa vida da mulher.

Segundo Cardoso de Oliveira (2002), a tradição entre os Terena era de enterrar os mortos junto com os seus pertences. Capitão Timóteo disse ao antropólogo que no enterramento de Ciciliano, exímio tocador de caixa (instrumento utilizado nas danças de bate-pau), ficou-se a meio caminho da tradição. A comunidade não enterrou o instrumento junto com o falecido, por influência dos enterros dos cristãos ou pelo valor do instrumento para a comunidade.

Ainda na fala de Timóteo sobre a morte de sua mãe, percebe-se as mudanças no ritual funerário após o contato com a sociedade envolvente:

[d]isse que, para ela, ele fez caixão ('Ihía-ku') e envolveu seu corpo em panos. 'Pusemos no caixão sem nada com ela. Mas naquele tempo antigo - diz o capitão - punham tudo na cova, porque não existia caixão. Queimavam a casa e matavam vaca e cavalo que [o morto] tivesse. Hoje nós já estamos acompanhando o civilizado, por isso que o enterro é diferente' (CARDOSO DE OLIVEIRA, 2002, p. 133).

O Dia de Finados para o povo Terena é dia de festa. Festa aos mortos! Cardoso de Oliveira constatou “... a revitalização de uma tradição, ou, em outras palavras, uma recuperação ritual de sua história" (2002, p. 236). A festividade inicia com caminhada que parte da igreja da 
aldeia, por volta das 7h30min da manhã, animada ao som dos sinos. A procissão percorre aproximadamente dois quilômetros, distância entre o cemitério e a igreja. Alguns caminham levando coroas, a maioria apenas rezando e/ou entoando cânticos católicos, até a parada diante do cruzeiro existente no centro do cemitério. Como a maioria se define como católica, os velhos, as mulheres e os jovens rezavam ou pareciam rezar ajoelhados ou de pé frente aos túmulos.

Apesar do prestígio e importância do Dia de Finados, o cemitério tinha aspecto de abandono e a explicação é no sentido de que os Terena "[t]ambém não gostam de limpar o cemitério porque acham que os espíritos dos mortos vão persegui-los" (CARDOSO DE OLIVEIRA, 2002, p. 205).

\section{Os Apinayé}

O traço marcante do rito funerário apinayé são as longas lamentações. O pranto é coletivo e realizado em casa, os familiares choram em volta do morto e as pessoas que mantêm entre si relações sociais tomam parte nos lamentos, mesmo que não haja parentesco sanguíneo com o defunto. A lamentação fúnebre inicia logo após a morte e, às vezes, até antes, quando a pessoa encontra-se extremamente debilitada, pois os Apinayé acreditam que os espíritos se reúnem em volta daquele que está prestes a morrer e oferecem comidas para que morra mais rápido.

Aos membros remanescentes do grupo cabe o dever de enfeitar o cadáver e enterrá-lo; em contrapartida, são considerados os principais herdeiros do morto, recebendo a maior parte da herança. Apenas o remanescente dos bens passaria para os filhos do morto. No ritual funerário, parte dos objetos é enterrada juntamente com o cadáver e as armas, os enfeites e os utensílios de casa são herdados pelas pessoas que estavam em relação de kram-kramgêd com o morto. Pelo exposto, conclui-se que tanto o direito de herança quanto o cuidado com os mortos dos Apinayé são influenciados pelas relações grupais.

O corpo do morto é lavado no terreiro e enfeitado com tinta de urucú e látex com pó de carvão. Os defuntos masculinos são, às vezes, 
também enfeitados com lã de pati. O corpo da pessoa morta é posicionado com a cabeça para o nascente e estendido sobre esteira no chão. Os cabelos são cortados e os enfeites são colocados a título de ornamentação. Os lamentos continuam durante algum tempo diante do cadáver ornamentado. Depois é carregado para o terreiro por meio da esteira, a qual é dobrada por cima do defunto e amarrada com duas alças de corda, em uma vara de madeira. Duas pessoas tomam as pontas do suporte de madeira nos ombros e seguem para o cemitério.

A sepultura é cavada há quase dois metros de profundidade. Quatro homens depositam o cadáver involucrado pela esteira, usando alças de corda. A cabeça fica para o lado do nascente. Os enfeites que o morto não leva no corpo são agora colocados; ao lado do corpo, de comprido: o arco e as flechas, ou, em se tratando de mulher, o cestinho de miudezas e o fuso. Por cima do corpo estende-se outra esteira e folhas de palmeira. Fecha-se a cova por meio de travessas cobertas de esteiras e folhas e depois se coloca a terra anteriormente escavada, de maneira que o cadáver não fique em contato com a terra.

Os pais e outros parentes próximos não acompanham o cadáver à sepultura, continuam a chorar no lugar onde o ornamentaram e quando os outros voltam do enterro, juntos vão ao ribeirão para se banhar.

O auge da desesperada manifestação de luto dos Apinayé por parte dos parentes do morto consiste em bater na cabeça e nas costas com acha de lenha, pedra ou algo semelhante que esteja disponível e empregando toda a força possível.

Nimuendajú (1956) relata o caso de duas mulheres que se atiraram, de certa altura, ao solo, em salto mortal, encontrando o barro duro do terreiro, de tal maneira que aparentavam terem quebrado, pelo menos, alguns ossos, o que não ocorreu. Mas há o caso da mãe que, ao carregar o corpo do filho morto, precipitou-se de cabeça para baixo do jirau, quebrando a nuca e morrendo. O salto mortal das mulheres enlutadas é chamado amny-i-mõ'tí. Os homens não vão tão longe nas manifestações de luto, mas estão sempre preparados para interferir.

Para os Apinayé, as almas dos mortos residem na própria superfície da terra, nos lugares onde viveram e foram sepultados. As almas dos que morreram assassinados vagam solitariamente, pois temem as outras e têm aspecto terrível, pois ostentam os ferimentos que o corpo recebeu 
em vida. Os espíritos, geralmente, não representam ameaça aos parentes vivos, exceto se cometerem graves negligências durante o funeral ou mesmo se praticarem subtração da parte dos espólios que lhes coube.

Os Apinayé acreditam que as almas dos feiticeiros executados causam pesadelos. No caso do assassinato de Yandorády, indígena acusada de matar várias pessoas usando de feitiçaria, há métodos preventivos empregados pelos algozes:

[c]avou-se imediatamente um buraco no qual se jogou o cadáver, enchendo-se a sepultura com terra bem socada. Depois todos que tinham tomado parte ativa na execução ingeriram grande quantidade de pimenta, pintaram-se com pontos prêtos e botaram enfeites de envira de tauarí. Durante muitos dias êles só comeram beijú com pimenta (NIMUENDAJÚ, 1956, p. 97, sic.).

Aqueles que receberam o batismo cristão não são enterrados no cemitério comum, mas sim separados dos demais. Os corpos inertes não são envolvidos com esteiras, confecciona -se urna de talos de buriti para sepultá-los. Entretanto, a sombra dos Apinayé "cristãos" compartilha inteiramente da sorte das companheiras pagãs, pois até então eles não conheciam os conceitos de céu, inferno ou purgatório das religiões cristãs.

Importa salientar que o luto da mulher apinayé pelo marido morto é idêntico ao praticado pelo marido ausente e perdura por aproximadamente três meses. Similar também o luto para pais e filhos, tio e sobrinhos, avós e netos, reciprocamente, não havendo, porém, reclusão rigorosa. O enlutado deixa crescer os cabelos, não se pinta e não participa das reuniões na praça. Os relatos de que o viúvo corta o cabelo em sinal de luto são, contudo, inexatos com relação aos Apinayé.

Quanto à prática do enterro secundário, Nimuendajú (1956) embasa os relatos do livro no depoimento de Iretí, que teria assistido, quando tinha 10 anos de idade, ao evento. Segundo a interlocutora, a cerimônia era levada a efeito pelas pessoas que estavam em relação de kram-kramgêd com o morto, isto é, os mesmos que faziam o enterro primário; realizava-se, mais ou menos, após decorrido um ano. No caso descrito por Iretí, a Kramgêdy, ajudada por algumas mulheres, recolhem os restos mortais de dentro da sepultura, juntando-os em esteira 
colocada ao lado. Carregam a esteira contendo os despojos para a casa materna do morto, onde lavam os ossos com água trazida pelo Kramgêdtí. Os ossos são enxugados ao sol e depois colocados dentro de casa e pintados com urucu, havendo em seguida lamentação fúnebre. Enfim, tudo vai em uma bolsa de buriti, que alguém levou ao cemitério e a enterrou em buraco de apenas um metro de profundidade.

Os guerreiros que morriam em terras inimigas e cujos cadáveres não podiam ser transportados para a aldeia eram enterrados no mesmo lugar, tratando-se, porém, sempre que possível, de recolher os ossos posteriormente, para posterior realização do enterro secundário.

Quando morre animal amansado, ou mesmo o cachorro, as mulheres o enterram da mesma forma como se fosse cadáver humano, muito embora não coloquem o luto.

\section{Os Tapirapé}

As descrições de Baldus (1970) sobre a morte e ritual funerário entre os Tapirapé encontram alicerce nos relatos feitos pelos próprios indígenas e são complementadas pelas anotações de outro autor, Kegel, que também realizou pesquisa junto ao grupo. $O$ autor alerta que não chegou a presenciar o evento morte e o subsequente ritual funerário durante a estadia no território:

[v]i muitos túmulos dentro das casas de Tampiitaua, mas não vi lá ninguém morrer e ser enterrado. Os meus dados a respeito do assunto se baseiam nas informações dos índios e naquilo que o meu companheiro Kegel observara em viagens anteriores (BALDUS, 1970, p. 300).

Baldus (1970) destaca logo de início que os habitantes de Tampiitaua sepultam os mortos dentro de casa; dessa forma, a quantidade de sepulturas no interior da maloca está diretamente relacionada à necessidade de mudança física do grupo e com a construção de nova aldeia. O processo é acelerado quando diante de desastres provocados por epidemias. Os mortos sepultados em aldeias abandonadas não são mais visitados. 
Segundo Baldus (1970), existe a possibilidade de se argumentar que os Tapirapé, à semelhança com os Javahé, também sepultavam os mortos no interior da casa, mas sem descartar a hipótese de que o grupo pratique a chamada sepultura secundária, à semelhança do que fazem os Karajá, os quais enterram o cadáver no cemitério, exumando os ossos depois da putrefação da carne e deitando-os em grandes urnas colocadas em lugar comum no solo. Baldus faz referência aos povos Tupi, que também, entre as práticas rituais funerárias, mantêm a prática de sepultar alguns mortos dentro de casa.

O lugar escolhido para a sepultura está relacionado com o local em que pendia a rede da pessoa antes de morrer. As covas de pessoas consideradas importantes, bem como as de seus familiares, são completamente revestidas de madeira, enquanto as covas para pessoas comuns possuem somente a plataforma de madeira colocada quase diretamente sobre o cadáver para protegê-lo da terra e apoiada em paus fincados verticalmente nos lados estreitos do buraco escavado.

O morto é enterrado na rede com a cabeça direcionada para o oriente e os pés para o ocidente, os braços estendidos ao longo do corpo, as pernas estendidas e sem nenhuma atadura.

Aos executados como feiticeiros ruins, é dispensado funeral sem solenidades e a sepultura não fica no interior da casa, são apenas soterrados no meio da mata em local que os parentes o possam lastimar. Para os pajés o ritual funerário é diferenciado. O pajé é enterrado com cachimbo cheio de tabaco na boca, de modo que possa fumar para extinguir a fadiga durante a viagem para maratawa; algumas vezes enterram alimentos com o corpo, para que ele possa alimentar-se durante a longa viagem até maratawa.

Destaca o autor que os Tapirapé não temem o morto, razão pela qual the aplicam urucu nos cabelos e jenipapo pelo corpo. Outros comportamentos inerentes aos cuidados que surgem por ocasião da morte de parentes é a necessidade de cortar rente os cabelos, obrigação estendida aos homens e às mulheres, do mesmo modo a pintura corporal com jenipapo, que marca o início e o fim do luto.

A aplicação do urucu nos cabelos parece, a Baldus (1970), ter significado religioso, pois é realizada no rapaz por ocasião da festividade de iniciação, na moça quando cessa a primeira menstruação e no morto 
no ritual funeral.

As marcas corporais oriundas das incisões ${ }^{11}$ feitas com escarificador (produzidos com os dentes incisivos de roedores afixados em pedaços de taquari), e cujas feridas são esfregadas com carvão, são realizadas geralmente com intuito de que o homem desenvolva a capacidade de carregar bem, são feitas, espontaneamente, nos homens depois da primeira relação sexual e após ser cortada a mulher ficava reclusa. Mas quando o homem mata outro ser humano, também deverá receber tais cortes, nesse sentido:

[a]ssim, quando Ané-gui, o cabeça dum bando guayakí, matava uma criança raquítica e incapaz de marchar, mandava fazer incisões no seu ombro prolongando aquêles que já tinha. Outro Guayakí explicou a respeito que o ombro encarangaria [entrevado, com movimentos restritos], se a gente não o iniciasse em tal caso. Há, porém, a possibilidade de uma coincidência casual da sarjação com o homicídio (BALDUS, 1970, p. 107, sic.).

Todos os bens do falecido são enterrados com ele. Junto aos cadáveres de mulheres e crianças são acrescidas panelas de barro, muito embora sem comida alguma. É costume tapirapé, observado por Baldus (1970), que o morto seja enterrado com todos os enfeites de pena; assim, a escassez de tais peças pode estar relacionada com as epidemias que dizimam a população e, por consequência, diminuem drasticamente os exemplares da arte plumária, que acompanham o morto na cerimônia de enterramento.

Existe, entre os Tapirapé, a festa dos mortos, que ocorre durante a maturação do milho, ocasião na qual são preparadas bebidas muito cobiçadas entre adultos e crianças de ambos os sexos.

\section{Os Aikewára ${ }^{12}$}

Os Suruí Aikewára, tal qual outros povos Tupi, como os Kaapor,

\footnotetext{
${ }^{11}$ A operação é realizada por um velho. Em cada lado da espinha dorsal as incisões descem dos ombros até as coxas. Alguns acrescentam ainda cortes horizontais nas coxas.

${ }^{12}$ Uma primeira versão da morte de Wa'a, cujo ritual funeral foi assistido por Luiza Mastop-Lima e Jane Beltrão, está contida em Beltrão, Mastop-Lima, Moreira (2008).
} 
estudados por Ribeiro (1996), acreditam na sobrevivência da alma. A crença foi registrada, ao longo dos anos de contato com a sociedade não indígena, por antropólogos que trabalharam e trabalham junto ao grupo. É Roque Laraia (1986)13 que, em estudo sobre povos Tupi, afirma que a crença na sobrevivência da alma, designada como owera, está relacionada à crença dos Tupi em Mahíra, herói civilizador.

Há, para os Tupi, segundo Laraia (1986), pelo menos três tipos de espírito: owera, a alma, que sai do corpo enquanto as pessoas dormem; asonga, o espírito dos mortos, que vaga pela terra até que seja chamado ao céu; e os karowara, espíritos especiais, que podem causar doenças e mortes quando descontrolados. No caso, os Aikewára referem-se aos espíritos dos mortos como asomera ${ }^{14}$, que também vaga pela terra até que se junte no céu aos karuára, espíritos dos pajés que morreram.

O céu é denominado pelos Aikewára, segundo Laraia (1986), como iwaga. É o lugar de morada de Mahíra e dos karuára; lá há fartura, a plantação não precisa de cuidados para produzir e ela mesma se colhe! É o lugar em que se canta, dança e no qual se celebram festas. Lá não se morre ao envelhecer!

Para chegar ao iwaga, o espírito dos mortos precisa percorrer um trajeto. Ele deve passar pela itakewára, a morada dos karuára na terra (LARAIA, 1986).

É importante conhecer/entender esse aspecto da cosmologia aikewára para que se possa ter possibilidade de compreender, a partir do ponto de vista dos interlocutores, o transtorno causado por corpos insepultos, mesmo quando o corpo não é aikewára, e sim kamará (não indígena), que o assassinado foi "desovado" na área que moram os protagonistas, pois os mortos, entre os Aikewára, assim como em qualquer sociedade, possuem tratamento diferenciado e marcado ritualmente.

No dia 19 de junho de 2003, os Aikewára enfrentaram a dor de "perder" a pessoa mais antiga entre eles, Wa' a, conhecida e chamada por todos de "Vovozinha". E para que Vovozinha pudesse completar seu ciclo de vida até ir ter com os karuára, foram necessários alguns cuidados, apesar da interferência da Igreja Católica. Vovozinha foi acomodada na

\footnotetext{
${ }^{13}$ Sobre o assunto, consultar Laraia (1986).

${ }^{14}$ Para maior compreensão da cosmologia aikewára, consultar Mastop-Lima (2002).
} 
urna funerária envolta em seus lençóis. Dentro da urna, conforme manda a tradição, foram postas suas roupas e seus pertences. Foi ornada com tinta de urucu e seu atutú15. A pintura facial de Vovozinha foi feita de modo a informar que ela era uma guerreira, uma figura emblemática para os Aikewára.

O ritual fúnebre foi marcado por "palavras de despedida" ditas na língua aikewára pelas pessoas mais velhas da aldeia, entre elas uma de suas filhas. O cacique Mairá e um dos netos de Wa'a também encomendaram a guerreira, mas o fizeram em português. Algo recorrente em todos os discursos foi o fato de Wa'a ter "morrido de velhice" e que agora ela poderia encontrar-se com os demais Aikewára que se foram antes dela.

Ter "morrido de velhice" é algo importante para a comunidade, pois Vovozinha também representava a vitória dos Aikewára contra a ameaça do desaparecimento, de sucumbir perante a sociedade não indígena. Desaparecimento este tão iminente na saga do grupo com a situação de contato, que ocasionou muitas perdas, ora "designadas" por doenças contraídas junto aos brancos, ora por tiros implacáveis disparados por kamará (não indígenas) desrespeitosos, ou mesmo pelo envolvimento involuntário na Guerrilha do Araguaia, como contam os indígenas com muita amargura ${ }^{16}$.

Para completar seu ciclo de vida, Wa'a teve de ser sepultada, quer pela condição da morte, quer pelo status de guerreira. E o foi num cemitério próximo à Aldeia Velha, ao lado de um de seus filhos, Kuimu'a, como ela havia pedido. A partir disso, Wa'a irá ter com os karuára e pode chegar ao iwaga.

É importante dizer que sua sepultura era funda o bastante para que nenhum animal pudesse alcançar seu corpo e dele se alimentar, pois isso seria prejudicial aos Aikewára, que têm verdadeira repulsa a um corpo em decomposição, seja ele de um ser humano ou de um animal. Isso lhes provoca sevarú (nojo) em muitas situações quotidianas. É Mastop-Lima quem ratifica a observação: "muitas vezes testemunhei essa repulsa

\footnotetext{
${ }^{15}$ Enfeite de cabeça feito com penas de arara ou tucano dispostas, em tufo em fios de algodão que são atadas à cabeça das mulheres, visto ser de uso exclusivamente feminino (MASTOP-LIMA, 2002).

16 Sobre o assunto, acessar os depoimentos aikewára à Comissão da Verdade em: http://www.cnv.gov.br/index.php/outros-destaques/483-cnv-recebe-relatorio-sobre-violacoes-de-direitosdos-indios-aikewara-surui-do-para.
} 
quando viajava com eles no carro da aldeia até Marabá ou a São Domingos do Araguaia. Se havia animal morto na pista, 'automaticamente' eles cuspiam, fecham as janelas e resmungam 'não saber por que kamará joga bicho na pista'"17.

Para os Aikewára, um corpo em decomposição é algo impuro. Impuros também e impróprios ao consumo ficam os animais que deste corpo se alimentam, pois se eles consumirem esses animais, ficarão doentes. Procurando evitar as doenças, o lugar onde foi jogado o corpo do kamará (não indígena), encontrado em 16 de março de 2003, passou a ser interditado para a prática das atividades tradicionais dos indígenas, diminuindo os espaços de movimentação do grupo em face do ocorrido.

O fato é prejudicial para o povo Aikewára tanto cultural como economicamente, uma vez que ali se situam as colocações ${ }^{18}$ de castanha de algumas famílias, um dos principais produtos por eles comercializados. Além do que, o lugar é uma das referências para a pesca, pois reúne algumas quotas dos escassos recursos hídricos que a eles restou depois da demarcação da Área Indígena Sororó.

Ter um espaço interditado às atividades necessárias à sobrevivência é preocupante em qualquer contexto, sobretudo entre os Aikewára, que enfrentaram e enfrentam problemas que, ainda hoje, provocam escassez de alimentos, como foi o caso do incêndio que atingiu a Área em 1996 e que se repete a cada estiagem nos últimos anos.

Além disso, o corpo jogado na Área representa a interrupção do ciclo de vida tal como o concebem os Aikewára. Os mortos devem ser enterrados de forma ritual. Jogar o corpo, mesmo de um desconhecido, no mato ou na pista é coisa de kamará (não indígenas), não de Aikewára. Da maneira como foi encontrado, o corpo, além de contaminar os animais, é um incômodo para os indígenas, pois o espírito do morto vaga num território que não é o seu, ele é um intruso no universo aikewára.

Como refere Tymykong:

aconteceu é, é... essa tragédia foi assim, coisa... é Luiza $^{19}$, o pessoal numa noite né, que Jurandir foi torar ${ }^{20}$

\footnotetext{
${ }^{17}$ Reflexão feita por ocasião da morte de Wa'a, quando por acaso chegamos à aldeia para produzir um laudo sobre os conflitos instaurados a propósito do corpo "largado" na terra Sororó, local onde se encontram os Aikewára (BELTRÃO, MASTOP-LIMA e MOREIRA, 2008).

${ }^{18}$ Locais de concentração de castanheiras propício à coleta do fruto e de suas amêndoas.

19 A referência à Luiza de Nazaré Mastop-Lima surge no depoimento em função da antropóloga,
} 
castanha, aí quando ele voltou encontrou os corpos do kamará lá na beira da pista né, aí, aí né, Jurandi veio falar com o povo aqui, e o pessoal foram ver, era um kamará que tava lá morto né, cortaram a cabeça dele, aí, numa noite a gente se uniu aqui e fizemo a interrupção da estrada né, porque eles 'tavam jogando lixo e cadáver, já quatro cadáver né Mairá? ${ }^{21}$ Que eles já acharam lá, tão jogando lixo velho lá também, aí, aí foi assim, aí começou, aí o pessoal, os homem tava tudo na beira da estrada, nós passamo duas noite que 'tavam né, com duas noite aconteceu esse negócio com esse homem, todos os caminhoneiro respeitou, só não ele que não respeitou ${ }^{22}$.

\section{Os Tembé/Tenetehara de Santa Maria do Pará}

A interlocução com os Tembé de Santa Maria do Pará, iniciada no contexto de etnogênese do grupo (BELTRÃO e LOPES, 2014), é permeada pela rememoração dos marcos da ocupação dos parentes antigos na região nordeste do Pará. Situados em aldeias diversificadas, posto que organizavam-se em núcleos familiares (WAGLEY e GALVÃO, 1955), os parentes são descritos em movimentos dentro do território: "Tinha uns que moravam aqui, outros ali...em todo canto", no dizer de Seu Miguel, Cacique da aldeia Areal. Todavia, as aldeias sempre são descritas como parte da trajetória histórica do grupo, justamente por nelas terem habitado os parentes vindos do Maranhão, ainda no século XIX.

Em fins desse século, agentes do governo do estado identificavam quatro aldeias, com nomes das famílias e localização, de acordo com o rio: Prata, Anselmo, Areal e Jeju. Na primeira, localizada no rio de mesmo nome, habitavam os Miranha; na segunda e terceira, ambas às margens do Maracanã, tinham como moradores dos Tupanas e os Leopoldinos; na última, banhada pelo Jeju, os Braz (FERNANDES, 2013). Todas essas aldeias, reconhecidas pelos Tembé contemporâneos, dão conta de um território tradicionalmente bem mais amplo do que as expectativas

\footnotetext{
costumeiramente, em períodos de campo, ter acompanhado os indígenas em atividade pelos castanhais.

${ }^{20}$ No sentido de cortar, como dizem os kamará, ou coletar castanha.

${ }^{21}$ Clara referência ao despejo de corpos na Área Indígena Sororó, eventos que se tornaram frequentes após a ampliação e o asfaltamento da BR-153.

${ }^{22}$ Depoimento da representante, apontada pela comunidade por intermédio do cacique Mairá, para narrar em reunião da comunidade as ocorrências que ensejaram a elaboração do Laudo, em 19.06.2003, na aldeia. (BELTRÃO, MASTOP-LIMA e MOREIRA, 2008, p.238-239, destaques do original).
} 
estatais supunham, considerando a circularidade do grupo no espaço. Hoje, no bojo das práticas colonizantes do Estado, as cidades, fazendas e estradas chegaram e ocuparam, com sua lógica indiferente, o que é memorialmente reconhecido como os lugares da história do povo.

Notoriamente, a tradição tembé possui marcos físicos que remontam a esse território: rios, antigas roças, castanhais e cemitérios. Estes últimos representam, ao mesmo tempo, um dos pontos nodais da trajetória desse grupo no Pará. Primeiro, por indicarem, pela memória histórica narrada, os pontos de referências às antigas ocupações e, do mesmo modo, onde descansam os parentes mortos; portanto, são eles parte da paisagem da memória e do respeito ao passado. Em segundo lugar, sobre eles recai, fatalmente, parte da dimensão de violência ensejada no processo de homogeneização: ao mesmo tempo em que são lembrados como lugares dos antigos, logo em seguida são lamentados como espaços da interdição, causada pela sua incorporação a fazendas e/ou destruição para exploração econômica.

Das descrições que possuímos, registradas em campo, contamos cemitérios em todas as aldeias. Para o Areal, há registros orais de duas necrópoles, uma delas dedicada somente a crianças, sob duas grandes castanheiras ainda hoje de pé. Segundo relatos, foi necessário a criação desse campo de enterramento por conta de surto de sarampo, mas sem indicação de datas ${ }^{23}$. O cemitério de adultos, segundo D. Maria de Nazaré, de 74 anos, não é sabido da sua localização, mas é lembrado, posto que escutasse de sua mãe as referências a ele, inclusive com a descrição de cruzeiro que o demarcava.

No Anselmo, assim ainda conhecido pelos indígenas, estão os parentes mais antigos. Atualmente dentro das cercas de uma fazenda, o cemitério foi o ponto de destino de caminhada organizada pela Associação Indígena Tembé de Santa Maria do Pará (AITESAMPA), gravada em vídeo. A viagem teve por função o reconhecimento, pelos mais jovens, do lugar de enterramento em antiga aldeia, símbolo da ocupação tembé no que viria a ser a cidade de Santa Maria do Pará. O retorno às origens, todavia, teve que ser negociado, tendo em vista a necessidade de autorização do fazendeiro proprietário das terras.

\footnotetext{
${ }^{23}$ Hemming (2009) faz registro das 30 Guajajara crianças mortas em decorrência de surto de sarampo, na missão capuchinha do Alto Alegre/Maranhão em 1900, estopim para revolta dos indígenas.
} 
O cemitério do Prata é referido na documentação história do século XX como "Cemitério Antigo de Sant'Antonio do Prata" (PARÁ, 1923-1938). Já antiga no início da década de 1920, a necrópole foi concebida para uso do educandário, criado em fins da década de 1890, para catequizar e "civilizar" as crianças tembé (MUNIZ, 1913). Das poucas referências que ouvimos dos indígenas a esse cemitério, sabemos que ele era feito ao estilo católico, com túmulos e lápides, além de cruzeiro em pedra e tijolos. Este último, aliás, é o único vestígio material observável em superfície, tendo em vista a destruição do campo santo por outro fazendeiro: após inserir em suas terras o lugar de enterramento, o posseiro destruiu as lápides, com fins de transmutar o local em pasto para gado, e, recentemente, iniciou extração de areia utilizada na construção civil.

Por fim, no Jeju, há registro oral de cemitério próximo ao rio homônimo à aldeia. Dona Judite, aos 60 anos, relata que quando era criança não viu nenhum enterramento sendo efetuado nesse campo santo. Todavia, o lugar era visitado com frequência por seu pai, que levava os filhos para participarem dos ritos de cuidado com os mortos lá sepultados, a maior parte deles crianças: acendiam velas, "enterravam" (plantavam) flores no solo arenoso da necrópole, arrumavam os túmulos e rezavam para os enterrados ${ }^{24}$. No lugar, com alguma frequência não especificada na interlocução, o pai de Dona Judite chegou a ouvir choros de criança. Isso ocorria quando o sepultamento era feito sem seu batismo, primeiro depois dos sete dias do funeral, depois aos 7 anos, "e assim por diante...". Quando o choro era escutado, o pai de Dona Judite batizava a criança e resolvia a situação da alma inquieta. A própria Dona Judite escutou esse tipo de choro em sua casa e fez o ritual de batismo. Segundo ela, já foi comum entre os Tembé enterrar seus bebês nos quintais das habitações dos pais, provavelmente pela não existência de cemitério para elas. Justamente esse cemitério do Jeju também foi explorado como areal!!!

As alusões aos cemitérios, como se vê, são poucas e não muito ricas em detalhes quanto aos lugares e modos de uso. Do mesmo modo,

\footnotetext{
${ }^{24}$ Dona Judite não recorda de enterramentos de adultos nesse cemitério. Já em seu tempo, as pessoas eram sepultadas nos cemitérios de Santa Maria ou de São Paulino (vila próxima ao Jeju). Seus avós foram enterrados neste último lugar.
} 
não acompanhamos algum ritual de enterramento ou mesmo de ida dos Tembé aos locais dos parentes antigos. O cuidado com o tratamento aos mortos, todavia, fica destacado na existência de cemitérios diversos, de quantidade quase igual ao número de aldeias. Ao mesmo tempo, nossa inserção entre os indígenas, para fins de pesquisa antropológica e arqueológica, colocou-nos diante de situação indicativa desses cuidados. A possibilidade de pesquisa nos locais foi recusada, mesmo que não se pretendesse algum tipo de prospecção intrusiva, justamente porque "não se mexe com os ossos dos parentes"! Ao lado disso, para o caso do Anselmo, foi destacado o local já era reconhecidamente tembé e que não era relevante pesquisá-lo, exatamente por essa razão. Por outro lado, parece-nos que falar dos parentes falecidos e seus lugares de enterramento para pessoas não indígenas não é conveniente, já que isso diz respeito apenas ao grupo. D. Judite, ao mencionar o assassinato de dois parentes, em tempos que a cidade se aproximava aos poucos das aldeias, lembra que os brancos viam os Tembé de modo preconceituoso, o que era consubstanciado nas "chacotas", juízos de valores e, nesse caso extremo, no assassinato de dois indígenas. Mortos "como se fossem dois cachorros de rua", seus corpos ficaram jogados na estrada, tratados dignamente apenas pelos parentes vivos.

\section{Gente de Verdade não Morre! Está sempre com a gente!}

O homem já era velho, devia ter mais de oitenta anos, ninguém sabia ao certo, dividia uma esposa com um parente e tinha filhos e filhas. Era considerado como um pajé forte e havia sido um grande guerreiro na juventude. Tinha sequelas da tuberculose que grassou entre os Asurini nos anos 1980, quase extinguindo o povo, sequelas com consequências agravadas pelos muitos anos como comedor de fumaça nos rituais de cura, nos quais o tabaco é utilizado como veículo portador de cura e substâncias revitalizantes do ynga, o princípio vital para os Asurini, "a força que faz o coração bater".

Ele estava internado há mais de um mês na cidade de Altamira, no Pará, fazendo tratamento. Morreu por lá, longe dos seus parentes, da sua terra... como se tratava de um caso de sequelas de tuberculose, a 
Fundação Nacional de Saúde (Funasa), responsável por "cuidar" do que resolveram chamar de saúde indígena, tratou de informar que "o corpo" seria enterrado na cidade mesmo, para evitar o risco de contágio na aldeia. Apesar do risco, toda a comunidade se mobilizou e as lideranças vieram para a cidade assim que a notícia chegou, para buscar o parente, agora embalsamado e lacrado em uma urna de madeira.

Os parentes da família e os demais parentes receberam o "morto" no porto da aldeia e seguiram em comitiva pelo tivagava 25 até o portão central norte da tavive26, ali todos choravam compulsivamente, as mulheres cobriam suas cabeças com panos e os homens cobriam os olhos com as mãos. O primeiro ato dos parentes foi romper o lacre e abrir a urna, ali inerte estava o parente trajando apenas uma fralda geriátrica, a indignação tomou conta de todos. Uma sobrinha se aproximou e perguntou: "Por que os brancos fazem isso com as pessoas, por que tiram até a roupa delas?" Um dos filhos, indignado, foi atrás das coisas que o pai havia levado quando foi para a cidade. Encontrada a bolsa, as coisas foram colocadas junto dele.

Os mais jovens e os parentes mais próximos, os amigos de caçada e de guerra, foram os primeiros a começar a cavar a sepultura depois que o wanapy ${ }^{27}$ demarcou o lugar onde ele deveria ser colocado, ao lado de outros pajés. Ali, com a urna aberta e os pertences que havia levado na viagem, o velho amigo assistia o choro desesperado dos parentes e amigos e o silêncio respeitoso dos rivais. Terminada a sepultura, sua mulher foi buscar uma tupapituna 28 , ali se colocaram todos os seus pertences aos quais estava mais ligado, seus enfeites, suas armas, seus facões e facas, roupas, depois ele próprio foi colocado ali, todos choravam copiosamente, alguns em desespero. Depois a rede foi fechada e depositada na sepultura, e todos os parentes se apressaram em cobrir logo com terra e terminar o trabalho. Terminado o serviço, houve silêncio na aldeia, os parentes, até mesmo os mais próximos, pararam de chorar,

\footnotetext{
${ }^{25}$ Pátio central da aldeia que fica na entrada central norte da tavive.

${ }^{26}$ A tavive é a "Casa Grande", uma formidável construção cônica, em palha, medindo cerca de 20 por 60 metros. É o espaço comunal do povo Asurini, local onde as rígidas regras de evitação do grupo são relaxadas, onde descansam os parentes que partiram para a outra vida e onde se realizam os longos e intricados complexos ritualísticos realizados pelo grupo.

${ }^{27}$ Espécie de guardião da tavive que atua como ajudante dos pajés nos rituais.

${ }^{28}$ Rede de dormir trançada com vários fios de algodão que a tornam extremamente grossa e resistente, contam os velhos que eram utilizadas como escudos durante as batalhas por serem muito grossas e não serem trespassadas pelas flechas.
} 
todos foram para suas casas, exceto a família daquele que sequer o nome poderia mais ser pronunciado a partir de agora. Em cima da sepultura, dentro da tavive, são colocadas as panelas de barro que foram utilizadas para fazer mingau para ele, e os bancos tradicionais de mogno nos quais ele se sentava, bem como os pertences que ele mais gostava e que não caberia na sepultura, em um dos esteios da casa eram pendurados seus machados mais antigos, e seu patawaja ${ }^{29}$. Todos os que moravam na mesma casa que ele tiveram que se mudar para outras casas até que construíssem outra, aquela casa onde ele morou os últimos anos deveria ser destruída e aqueles bens considerados de maior valor e que não poderiam ser colocados com ele seriam dados de presente para parentes distantes. Os parentes próximos todos deveriam mudar de nome para outros dos muitos nomes que recebem por herança quando nascem, a não observância desse preceito poderia matar a pessoa de tristeza.

O seu nome não poderia mais ser pronunciado a não ser quando da realização do complexo ritualístico das flautas, quando os jovens iniciados pulam a grande panela de barro com adornos antropomórficos feita no centro da tavive, chamada de tauva rukaia, apenas nesse momento, que ocorre em média a cada dois anos, de acordo com os sonhos dos pajés, é que seu nome pode ser pronunciado e os velhos e os parentes contam que ele descansa ali e que havia sido um grande guerreiro, um pajé, que um dia também havia pulado a tauva rukaia. Todos choram de forma ritualística e depois não pronunciam novamente o nome dos que ali descansam.

Quando ocorre de terem que se mudar para outra aldeia, os wanapy se encarregam de coordenar a construção de uma nova tavive e tão logo ela fique pronta, eles e os pajés vão até a antiga tavive, recolhem os restos mortais dos parentes e os levam para "plantar" na nova tavive.

A tavive, imponente no centro da aldeia, centro da vida cerimonial do grupo, espaço comunal, torna-se, por assim dizer, o espaço de convergência dos mundos natural e espiritual, segundo os pajés "avaete30 mesmo não morre, está sempre por aqui perto de gente, na tavive e

\footnotetext{
${ }^{29}$ Suporte trançado de algodão e taquara para pequena panela ritualística de mingau, símbolo de que ele era um pajé, bem como os últimos cigarros de tauari feitos por ele.

${ }^{30}$ Etnônimo do grupo que significa "gente de verdade".
} 
quando tem festa eles vêm e dançam no meio de gente mesmo".

A família sempre cuidará de manter o local limpo, varrido, às vezes coberto por plásticos, com os objetos do finado sempre por ali e dizem: "Ele não tá mais nesse mundo, ele tá vivo no outro mundo, mas ele também tá aqui um pouquinho".

O nome do finado, na maioria das vezes, só poderá ser dado a alguém depois de pelo menos uma geração, quando sua coleção de nomes for dada a alguma criança de sua família. Para os Asurini, diferentemente dos ocidentais que acreditam, na maioria dos casos, que após a fecundação do óvulo existe uma nova vida, a pessoa humana só se constitui quando o cordão umbilical cai e os mais velhos escolhem, na maioria das vezes através de sonhos, que nome a nova pessoa terá. A paternidade é considerada pelos antropólogos como difusa, o que significa que para o nosso povo a nova vida vai se fazendo aos poucos, à medida em que a mulher vai tendo relações sexuais e o feto vai sendo formado, por isso é bom ter muitas relações quando se engravida e, culturalmente, de preferência, com o maior número de homens possível, para que as duras regras de parentesco e evitação do grupo sejam amenizadas para a criança quando ela se tornar gente. Ao receber 0 nome ela se torna uma pessoa e, com o nome herdado, muitas vezes herda também as características e funções sociais de seus antigos donos.

Nas rodas de conversa, à noite, depois de tocar flauta, os pajés explicam que o nosso povo está sempre junto, os que estão aqui e os que estão no outro mundo, chamado de $y v a k a^{31}$, por isso sempre tem que ter tavive, para que eles, os que estão lá possam descansar. Toda a vida cerimonial e a comunhão do povo, as festas, os ritos de passagem acontecem por ali, por isso eles participam de tudo, segundo os pajés. A vida avaete engloba de forma intrínseca o que a sociedade ocidental chama de morte, os que partiram estão ali por perto, sendo cuidados e cuidando dos seus, como dizem os velhos, não identificam mais suas antigas casas porque elas foram destruídas, não distinguem seus parentes próximos porque eles não têm mais os mesmos nomes, não Ihes podem causar tristeza e nem lhes fazer mal, porque agora moram no lugar que é partilhado por todos, onde as regras de parentesco e evitação são relaxadas, onde todos são iguais.

${ }^{31} \mathrm{O}$ céu morada dos seres espirituais míticos e daqueles que partiram desse mundo. 
A vida terrena termina quando se extingue o ynga, 32 que passa a existir em outro plano, onde tem contato com os pajés ancestrais, os heróis míticos e os pajés deste mundo quando acontecem os rituais. A não observância dos ritos funerários pode ocasionar a ruptura do ynga espiritual, dando origem aos anynga ${ }^{33}$, que assombram as pessoas da aldeia, causam doenças e malefícios e, por vezes, entram nas pessoas até que os pajés os possam mandar embora através de rituais.

\section{Os cuidados com os mortos refletem o desvelo com a vida}

Os registros e relatos expostos ao longo do texto permitem, apesar das lacunas de informação existentes, esboçar um quadro relativo a práticas funerárias de comunidades indígenas. As descrições permitem identificar os lugares de sepultamento, o uso do território, as circunstâncias de uso, as mudanças ocorridas e, sobretudo, se aperceber da humanidade dos povos indígenas via o cuidado com os mortos e a morte, procurando manter o equilíbrio das relações sociais na aldeia e para além dela. Considerando isto, cabe a reflexão acerca das possibilidades de verificação desses contextos no registro arqueológico.

Das leituras aqui coligidas, fica evidente o uso da rede enquanto "contentor funerário" por diversos grupos - Ka'apor e Asurini. Em alternativa, pode também ser utilizada uma esteira para essa função Apinayé. Tais práticas, de uso de elementos de contenção do cadáver de origem vegetal, resultam frequentemente em constrangimentos das movimentações dos elementos anatômicos durante o processo de decomposição e podem, em certas ocasiões, originar posicionamentos específicos dos remanescentes ósseos - por força do chamado "efeito de parede". Um dos potenciais efeitos provocados pela deposição dos cadáveres em decúbito dorsal no interior de uma rede ou esteira (produzindo uma situação semelhante a "ataduras") seria a verticalização das clavículas, ou seja, um posicionamento mais vertical das clavículas, tendencialmente paralelas à coluna vertebral, acompanhado de uma projeção anterior dos ombros (DUDAY, 2006; DUDAY et al., 1990). Em

\footnotetext{
${ }^{32} \mathrm{O}$ princípio vital asurini, a força que faz o coração bater. A força que faz mover sem ser movida.

${ }^{33} \mathrm{O}$ "eu" despedaçado.
} 
contexto de pesquisa arqueológica, estas situações poderiam eventualmente ser reconhecíveis, acaso algum desses enterramentos fosse recuperado suficientemente preservado. No caso específico dos Ka'apor, é relatado o fato de que nem sempre o cadáver enrolado na rede é alvo de enterramento.

Outro aspeto perceptível com base nas fontes aqui consideradas é a preparação minuciosa de algumas das estruturas funerárias, aparentemente com o objetivo de evitar o contato direto do cadáver com a terra - Apinayé e Tapiparé. Também esse preceito apresenta implicações nos processos de decomposição dos cadáveres, uma vez que, se a sepultura não se apresenta totalmente colmatada, poderão existir deslocações de elementos anatômicos, pela existência de espaços vazios que permitem movimentações que, de outro modo, não ocorreriam. Nesse caso, a desorganização dos elementos ósseos poderia dar a falsa impressão de que estaríamos perante um contexto de inumação secundária (DUDAY, 2006). Verificando-se, pelo menos no caso dos Apinayé, a subsequente realização de inumação secundária, deverá ser altamente improvável que algum desses enterramentos primários venha a ser identificado em campo. No entanto, é uma prática que merece alguma atenção, na medida em que possam vir a surgir contextos preservados com características semelhantes.

Comuns são também os espólios votivos acompanhando os falecidos, geralmente compostos de pertences pessoais, como é observável nas informações sobre os Ka'apor, Terena, Apinayé, Tapiparé, Aikewára e Asurini.

Um dado parece se tornar evidente deste conjunto de informações, o cuidado colocado por diversas comunidades indígenas no tratamento dado aos mortos. Desde logo visível no simples fato de se desenvolverem práticas de enterramento que, por vezes, envolvem estruturas elaboradas, esse aspeto fica também marcado em questões como o estabelecimento de preceitos funerários diferenciados (em alguns casos determinados por questões como a faixa etária do falecido, em outros relacionado ou com as circunstâncias da morte ou com o papel desempenhado por esse indivíduo na comunidade) ou nos gestos integrados nas cerimônias fúnebres, como sejam o decorar do cadáver previamente ao seu enterramento. 


\section{Referências bibliográficas}

BALDUS, Herbert. Tapirapé: tribo indígena do Brasil Central. São Paulo: Cia. Editora Nacional/EDUSP, 1970.

BELTRÃO, Jane Felipe; LOPES, Rhuan Carlos dos Santos. Diásporas, homogeneidades e pertenças entre os Tembé Tenetehara de Santa Maria. Aceno, Cuiabá, v. 1, n. 1, p. 123$143,2014$.

BELTRÃO, Jane Felipe; MASTOP-LIMA, Luiza de Nazaré; MOREIRA, Hélio Luiz Fonseca. De vítimas a indiciados, um processo de ponta-cabeça: Suruí Aikewára versus Divino Eterno - Laudo antropológico. Espaço Ameríndio, Porto Alegre, v. 2, n. 2, p. 194-258, 2008.

CARDOSO DE OLIVEIRA, Roberto. O diário e suas margens: viagem aos territórios Terêna e Tükúna. Brasília: EdUnB, 2002.

DUDAY, Henri. L'archéothanatologie ou l'archéologie de la mort (Archaeothanatology or the Archaeology of Death). In: GOWLAND, Rebecca; KNÜSSEL, Christopher (Org.). Social Archaeology of Funerary Remains. Oxford: Oxbow Books, 2006. p. 30-56.

DUDAY, Henri et al. L'Anthropologie "de Terrain": reconnaissance et interpretation des gestes funéraires. Bulletins et Mémoires de la Société d'Anthropologie de Paris, Paris, n. 3-4, p. 29-50, 1990.

FERNANDES, Edimar Antônio. Luta por direitos: estudo sobre a Associação Indígena Tembé de Santa Maria do Pará (AITESAMPA). 2013. 188 f. Dissertação (Mestrado em Direito) - Programa de Pós-Graduação em Direito, Universidade Federal do Pará, Belém, [2013].

GALVÃO, Eduardo. Diários de campo de Eduardo Galvão: Tenetehara, Kaioá e índios do Xingu. Rio de Janeiro: Ed. da UFRJ/Museu do Índio-FUNAI, 1996.

HEMMING, John. Fronteira amazônica: a derrota dos índios brasileiros. São Paulo: Editora da Universidade de São Paulo, 2009.

LARAIA, Roque de Barros. Tupi: índios do Brasil atual. São Paulo: EdUSP, 1986.

MASTOP-LIMA, Luiza D. N. O tempo antigo entre os Suruí/Aikewára: um estudo sobre mito e identidade étnica. 2002. 140 f. Dissertação (Mestrado em Antropologia) Programa de Pós-Graduaçao em Antropologia, Universidade Federal do Pará, Belém, [2002]. 
MENÉNDEZ, Miguel A. A área Madeira-Tapajós: situação de contato e relações entre colonizador e indígenas. In: CARNEIRO DA CUNHA, Manuela (Org.). História dos Índios no Brasil. São Paulo: Cia. das Letras, 2002. p. 281-296.

MUNIZ, Palma. O Instituto do Prata (Município de Igarapé-Assú). Belém: Typ. da Livraria Escolar, 1913.

NIMUENDAJÚ, Curt. Os Apinayé. Boletim do Museu Paraense Emilio Goeldi, Tomo XII, 1956.

PALGI, Phyllis; ABRAMOVITCH, Henry. Death: a cross-cultural perspective. Annual Review of Anthropology, n. 13, p. 385-417, 1984.

PARÁ. Registro dos Attestados de Obitos ocorridos na Lazaropolis do Prata. Santo Antônio do Prata: s/e, 1923-1938.

RIBEIRO, Darcy. Diários índios: os Urubu-Kaapor. São Paulo: Cia. das Letras, 1996.

WAGLEY, Charles; GALVÃO, Eduardo. Os índios Tenetehara, uma cultura em transição. Rio de Janeiro: Ministério da Educação e Cultura, 1955.

Recebido em: 18/04/2015 * Aprovado em: 08/06/2015* Publicado em: 30/06/2015 